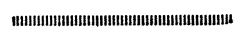

技術 報告

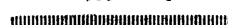

UDC $\quad 621.771 .22: 669.012 .5$

\title{
クロップロスの発生を抑制する新しい分塊圧延法
}

\author{
松崎 実*·金成 冒平*2.小川 靖夫* ·中里 ${ }^{*}$ 嘉夫*
}

\section{A New Method of Slab Rolling for Prevention of Growth of Crops}

Minoru Matsuzaki, Syohei Kanari, Yasuo Ogawa, and Yoshio Nakazato

\begin{abstract}
Synopsis:
We have developed new slabbing methods to reduce the crop losses remarkably. The new methods were devised after investigating the basic deformation behavior at both ends of the slab during slab rolling.

In particular there are two methods, namely, "Bite Back Rolling method" and "Ultra High Reduction Slabbing method", and both are effective in minimizing the crop losses. As a result of applying the two methods to an actual mill at our works, Kawasaki Steel Corp., a slab yield of 96\% after conditioning of capped steel was attained by the Bite Back Rolling method, and the slab rolling yield of capped steel increased by $4 \%$. A slab rolling yield of $97.5 \%$ for AISI 430 was attained by the Ultra High Reduction Slabbing method.
\end{abstract}

\section{1. 緒}

分塊工程で発生するロスの中で，最る量的に多いのは 分塊圧延中に厚み方向に折れ込むオーバラップと，幅方 向中央部より端部が突出したフィッシュテールとからな る,クロップと呼ぶ不良部の切り捨てであり，このロス は, 鋼塊重量の $5 \%$ 以上を占めていた. 分塊圧延工場に 护けるコストの中で歩留りの占める割合は大きいことか ら,フィッシュテール長さを減少させ，スラブ先後端の 平面形状の矩形化，および，クロップの切り唅て位固を 決定するオーバラップ長さの低減などにより，このロス を極限まで減少させることは極めて重要である.

従来から，クロップロスの改善策としては，鋳型形状 の改善1)2) やパススケジュールの適正化方， あるいはウ ェル定盤形状・寸法の改善《などにより，步留りの向上 が計られているが，これらの方法では設備的な制約や造 塊条件の問題などにより，その効果に限界があつた.す なわち，製造頻度の高いスラブサイズを考虑した鋳型か ら鋼塊は製造されるが，通常，一種類の鋼塊から，多種 類のサイズのスラブが製造される.このため鋼塊からス ラブまでの幅圧下量あるいは厚み圧下量の増加に伴い, クロップロスの增加を招き，压延するサイズによらず歩 留りを向上させることは困難であつた。

そこで著者らは，実機における分塊圧延時の各パスご
とのメタルフローに着眼し，鋼を用いたモデル実験によ り非定常部の基本的な変形举動を詳細に検討した結果か らクロップの形状改善法を見出し，設備などは現状のま までより一層の歩留り向上を得る，いくつかの新しい分 塊圧延法を開発した. これらは，压延法の特徽から，嘴 み㞍し压延法(5) 10)。バーチカルフリー法11)。強圧下引 き抜き圧延法12)13)。I 字型圧延法14) と呼んでいるすの で, 現在, これらの技術は当社千葉製鉄所・水島製鉄所 の各分塊工場に拈いて実用化し，大きな成果を得ている ので以下に報告する.

\section{2. 非定常部の変形举动}

從来圧延法に抢けるクロップの生成機構を概略説明す る. 水平ロールと垂直ロールを具備したユニバーサル压 延機により，鋼塊からスラブに圧延する場合，压延初期 の数パスは，鋼塊表面の脱 1 次スケールと鋼塊のテーパ 一消去のために，水平ロールて銅塊の幅方向の圧延を行 う.このとき, 長手方向両端にはフィッシュテールが生 成されて，厚み方向にはドッグボーンと呼ばれる局部的 な厚みの增加が生ずる。

その後, 被圧延材は $90^{\circ}$ 転回されて，水平ロールによ る厚み方向の圧延に移行するが，厚み方向に折れ込むメ タルフローによりオーバラップの成長が開始する．同時 にドッグボーン部が压延されて，フィッシュテールを成

昭和 56 年 3 月 12 日受付 (Received Mar. 12, 1981)

* 川崎製鉄(株)千葉製鉄所 (Chiba Works, Kawasaki Steel Go., Ltd., 1 Kawasaki-cho Ghiba 260)

*2 川崎製鉄(株)技術研究所 (Research Laboratories, Kawasaki Steel Corp.) 
Table 1. Experimental Conditions.

\begin{tabular}{|c|c|c|}
\hline \multirow{3}{*}{$\begin{array}{l}\text { Model ingot } \\
\text { (1/10 of } 18- \\
\text { ton steel iogot } \\
\text { equivalent) }\end{array}$} & \multirow{2}{*}{ Size } & $1 \quad \begin{array}{ll}60 t_{\bullet} \times W_{0} \times 250 l_{0} \\
& (98,108,118 \mathrm{~mm})\end{array}$ \\
\hline & & $\begin{array}{cc}t_{0} \times 118 W_{0} \times 250 l_{0} \\
\quad\left(t_{0}=40,60,80 \mathrm{~mm}\right)\end{array}$ \\
\hline & Material & $\begin{array}{l}\text { Low manganese killed } \\
\text { steel }\end{array}$ \\
\hline s & Shape & $\begin{array}{l}\text { Parallel piped, all } \\
\text { sides finished }\end{array}$ \\
\hline \multicolumn{2}{|c|}{ Rolling reduction } & 3 to $10 \mathrm{~mm} /$ pass \\
\hline \multicolumn{2}{|c|}{ Rolling temperature } & $1000 \pm 50^{\circ} \mathrm{C}$ \\
\hline \multicolumn{2}{|c|}{ Rolling roll dia. } & $120 \phi \mathrm{mm}$ \\
\hline \multicolumn{2}{|l|}{ Rolling speed } & $7 \mathrm{~m} / \mathrm{min}$ \\
\hline
\end{tabular}

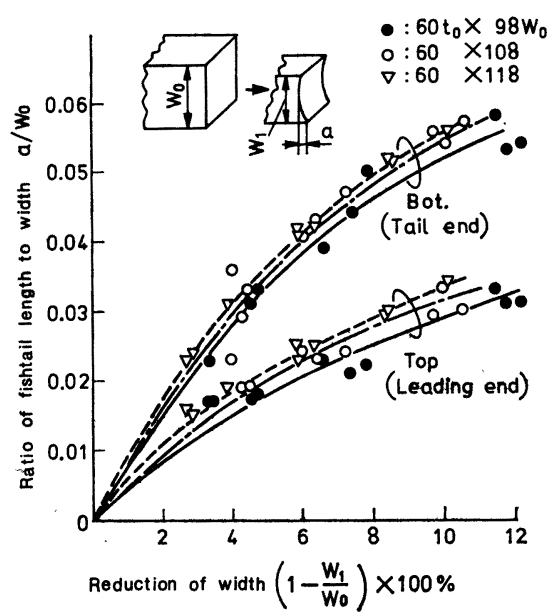

Fig. 1. Relation between reduction of width and ratio of fishtail length to width.

長させ，また，一部は幅に㞍る. 以後の 10 数回の幅圧 延と厚み圧延との相互作用によるクロッブェンドへのメ タルフローにより，フィッシュテールとオーパラップが 著しく助長される.

この端部における変形は, 理論的な解析がなされてお

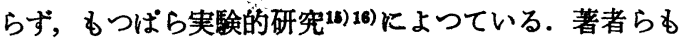
分塊圧延時の変形挙動を明らかにするため, 1/10 縮尺の 鋼を用いたモデル実験を行つた. Table 1 に実験条件を 示す.

\section{1 压䃌の影要}

幅圧延時には，啮み込み端と噒み抜け端にフィッシュ テールを生成させ，愿み方向にはドッグボーンを形成さ せるメタルフローが起こる。

Fig. 1 に幅圧延 1 パスに打ける啮み込み端, 及び啮み

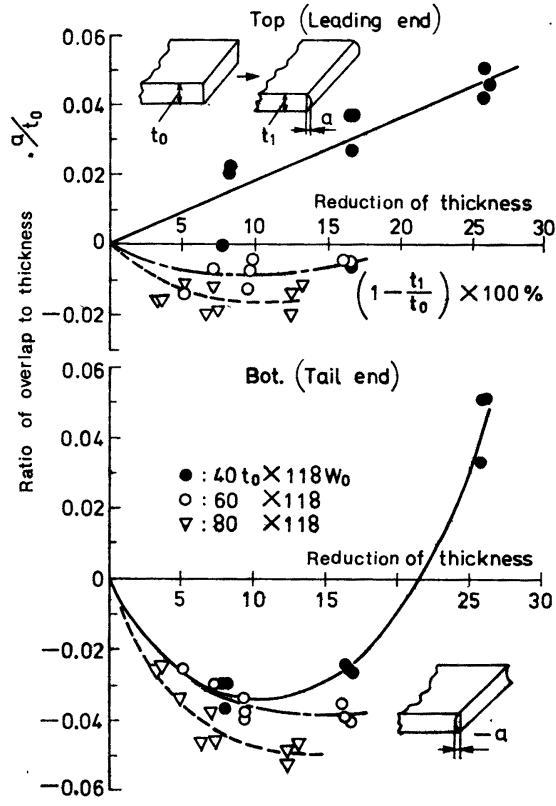

Fig. 2. Relation between reduction of thickness and ratio of overlap to thickness.

抜け端の，おのおののフィッシュテール長さ比と圧下率 の関係を示す。いずれの銅塊幅においても，啮及抜け端 が著しく大きくなることがわかる.この現象は, 啮み込 み端，定常部扎よび啮み抜け端に括いて，ロールと素材 の接触圧力分布に差があるためと推察される.

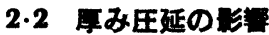

厚み压延時には，嘴み込み端と啮み拔け端にオーバラ ップを形成する．このとき，幅方向にもメタルフローが あつて, 定常部の幅に比して両端部でより大きい幅広が りを起こす。

Fig. 2 に厚み圷延 1 パスに打ける,啮み込み端，及び 啮み拔け端の，おのおののオーバラップ長さ比と圧下率 の関係を示す.

これから，舑み込み端側は，啮み抜け端側に比較して， オーバラップ長さが小さくなる傾向が浔められる. しか しながら，厚み圧下においてすべてにこのような傾向を 論ずることができず，特に鋼塊厚み，あるいは圧下率に よりオーバラップ長さが著しく変化することは着目すべ き事実である.

次に，厚み圧延 1 パスに拈ける，モデル鋼塊厚別の長 手方向の侧面形状の変化を Fig. 3 に示す.

觜及込み・嘴み拔け先端部では，側面形状がシングル バレルとなつているが，他の部分ではダブルバレル状に なることがわかる. 


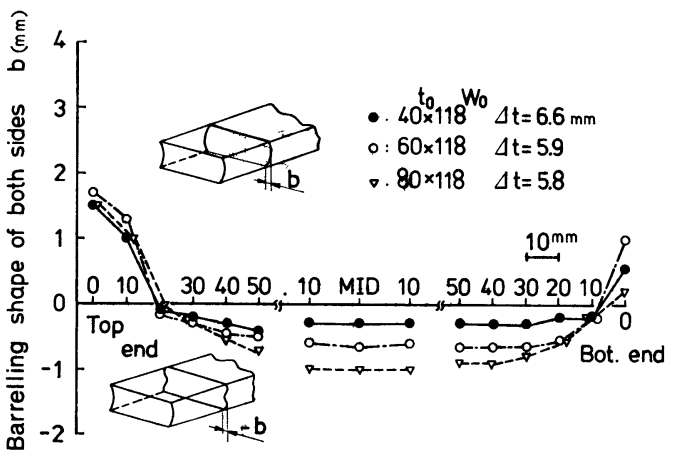

Fig. 3. Barrelling of side surfaces of slab.

\section{3. 新しい分塊圧延法の基本原理}

2 章の実験的研究，及び実機に拉けるメタルフローの 観察から考えられたクロップ形状改善のための，新しい 分塊圧延法の基本原理は，以下に述べるとおりである.

\section{1 啨み厍し圧延法}

（1）分塊圧延のように比較的圧下率の小さい場合に は上記 $2 \cdot 1,2 \cdot 2$ に示す事実から，嚙み込み端に比較し て，啮み拔け端側のオーバラップ・フィッシュテールが 大きくなる。

そこで，このようにクロップェンドに流出する多量の メタルフローをなくすには，圧延用ロールにより凹部を 形成し，この部位を畋み拔け端とし，凹部でメタルフロ 一を吸収すればよいことになる。

これが，啮み戻し圧延法の第一の基本原理である.

（2）（1）の圧延用ロールによる四部の形成を厚文 方向に実施すると，厚みの減少に伴い，圧下率が相対的 に大きくなり中心近傍まで変形が及ぶのと同時に，幅中 央では，ロールに摩擦拘束されるために，偪方向に流れ ずに長手方向に延びて行き，オーバラップ長さが減少し てきて，啮み込み端の厚み方向中央部を突出させること る可能となる.これが，第二の基本原理である.

ここで，凹部の形成を 端部にとどめているのは Fig. 3 からわかるよらに，压延後のスラブ側面の 厚み中央 に，乙わ欠陥を発生させないためであり，かつ，圧延能 率の低下を防止するためである.

\section{2 バーチカルフリー法}

一般的には；分塊圧延初期段階でわずかでもフィッシ ニテールを生成させると, 厚み圧下による被圧延材の厚 みの減少に伴つて延伸されて, クロップロスを増大させ ることになる. 従つて幅圧延の時期は, できるだけ断面 厚が減少してから行らのがよいことになり, 同時に必要 最少限の幅圧延回数とするのがよいのはよく知られてい る17).
厚み方向の噌み戻し圧延により形成された凹部の先端 は凸型の平面形状を呈することと，フィッシュテールを 形成する幅圧下と幅圧下をしないパス（バーチカルフリ 一）を適正に組み合わせることにより，フィッシュテー ルを生成させないパススケジールをバーチカルフリー 法と言う。

\section{3 強圧下引き抜き匠延法}

Fig. 2 から,嚙み拔け端側のオーバラップは，1 パス 当たりの圧下率を大きくすることで減少することが示唆 された. しかし，1 パスごとの圧下量は，王延機の能 力・素材の変形態などによつて異なるが，一般的には， 啮み込み限界・トルク限界・荷重限界からの制約により 決められている. 著者らは, 千葉第 2 分塊圧延機に打け る通常圧延法の限界として, Table 2 に示す経験値や, Table 3 に示す変形抵抗の比較などから，より大きな圧 下量・圧下率を採るには，トルク限界・荷重限界からく る制約よりも啮み込み限界によつて制約されると考え た.

そこで，嚙み拔け端部の圧下率を増大させる方法とし て，啮み拔け端部を残し，啮み込み端側を減厚していつ て，ある時期にそのままパスを抜き去ることにより，嘴 み拔け端は压下率圧延が可能となることを見出した。

これが本圧延法の基本原理である.

\subsection{I 宇型压延法}

通常の分塊圧延法では，スラブ中央幅に対し，両端が 狭幅となる，いわゆる太鼓形状を呈する。オーバラップ 長さが大きい場合には，この部分はクロップとして除去 されるが，各種の改善によるオーバラップ長の减少によ り，両端の狭幅部はスワブとして残ることになるので, 両端部の幅精度の向上は単に分塊歩留りにとどまらず, 次工程歩留りの向上がらも重要である。

そこで, 両端幅狭部の改善は, 中央幅を減少させれば よいといら考学から，圧延用ロールにより，被圧延材を

Table 2. Max. bite angle of conventional rolling.

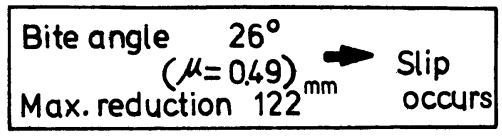

Table 3. Comparison of deformation resistance.

\begin{tabular}{|l|c|c|c|}
\hline Steel grade & Mould & $\begin{array}{c}\text { Deformation } \\
\text { resistance }\end{array}$ & $\begin{array}{l}\text { Roll ing } \\
\text { temperature }\end{array}$ \\
\hline AISI 430 & $\begin{array}{c}57.1 \mathrm{~V} \\
58.5 \mathrm{~V}\end{array}$ & $3.5^{\mathrm{kg}} / \mathrm{mm}^{2}$ & $1050^{\circ \mathrm{C}}$ \\
\hline $\begin{array}{c}\text { Rimmed } \\
\text { steel }\end{array}$ & $\mathrm{C} 18 \mathrm{C}$ & $6.8 \mathrm{~kg} / \mathrm{mm}^{2}$ & $1000^{\circ \mathrm{C}}$ \\
\hline
\end{tabular}


幅方向にわずかに締め込んで，ロールを両端クロップェ ンドより抜かない数回の往復圧延で，I 字状に平面形状 を調整することによつて可能となることを見出した. こ れが I 字型圧延法の基本原理である.

\section{4. 各程圧延法と非定常部の変形挙動}

\section{1 望み屈し压延}

Fig. 4 に, 嚙み戻し圧延法を示す. まず，（1)のよう にロール開度を $\mathrm{T}_{1}$ にセットして, 啮み込み直後にロー ルの回転を逆転して材料を戻し凹部を形成する. その 後，(2)のようにロールをシフトして圧下を加えずに材 料を送り（3)のようにロール開度を $\mathrm{T}_{2}$ にセットして 未圧延部を逆方向から圧延し，メタルをクロップエンド へ流出させずに凹部で吸収する.

この圧延法は, 圧延過程の適当な時期に，厚みおよび 幅方向端部に凹部を形成することができ，最終的に極限 まで小さなクロップを得ようとするすのである.

啮み戻し圧延による凹形成部位の変形挙動を明確にす る目的で，モデル鋼塊を用いた実験を行つた.

$80 \mathrm{~mm} t_{0} \times 118 \mathrm{~mm} W_{0} \times 250 \mathrm{~mm} l_{0}$ のモデル鋼塊の厚み
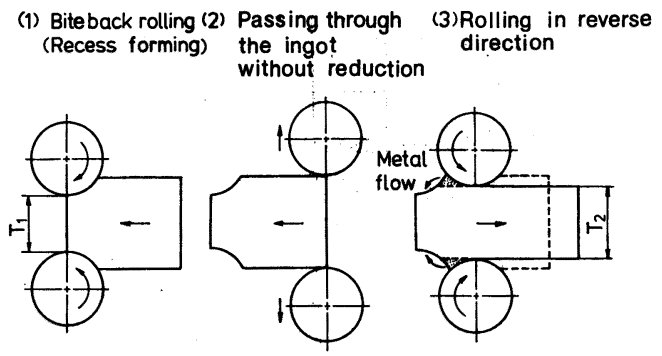

Fig. 4. Bite back rolling process.

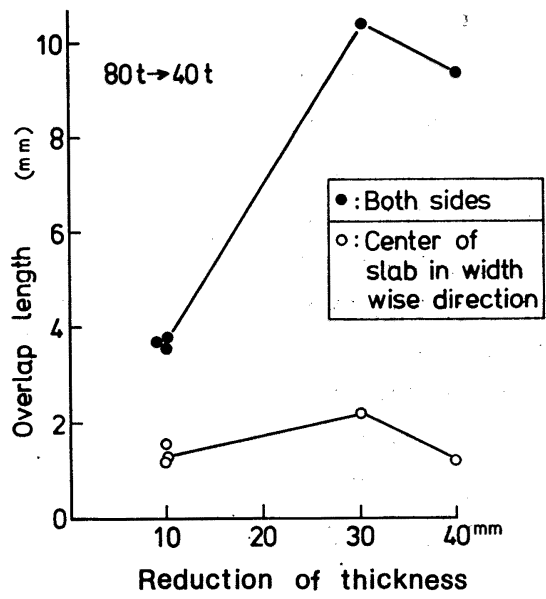

Fig. 5. Changes in overlap at slab ends (reduction of thickness per pass ; $10 \mathrm{~mm}$ ).
方向の一端に，嚙み戻し圧延で凹部を形成した。

この時の凹部の形成は, 圧下量 $10 \mathrm{~mm}$ ずつの嚙み戻 し圧延で $40 \mathrm{~mm}$ 厚まで実施した.この条件下に拈ける 凹部先端のオーバラップ長さの変化を, Fig. 5 に示す.

これから，いつたんできたオーバラップが回復してく れることがわかる。

また，モデル鋼塊执よび実鋼塊を用いた実験から，啮 み戻し圧延をした部分の幅広がり量は, 長手方向中央部 より大きく，スラブ幅精度が向上することを確認してい る・) 10).

\section{2 強圧下引き抜き圧延}

Fig. 6 に, 強圧下引き抜き圧延法の模式図を示す. 梏

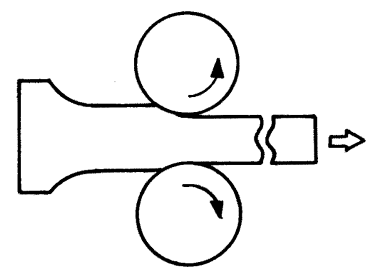

Fig. 6. Schematic representation of ultra high reduction slabbing method.

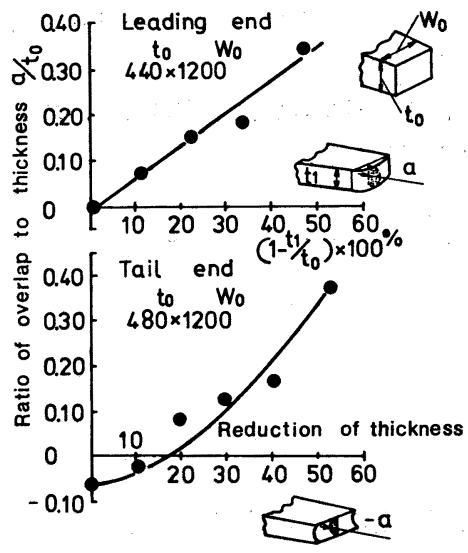

Fig. 7. Relation between reduction of thickness and ratio of overlap to thickness. (Actual ingot).

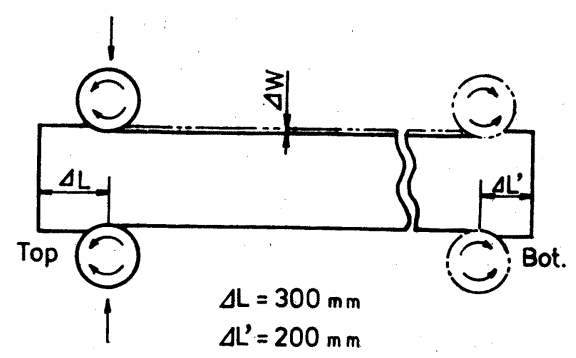

Fig. 8. 1-shaped rolling method. 


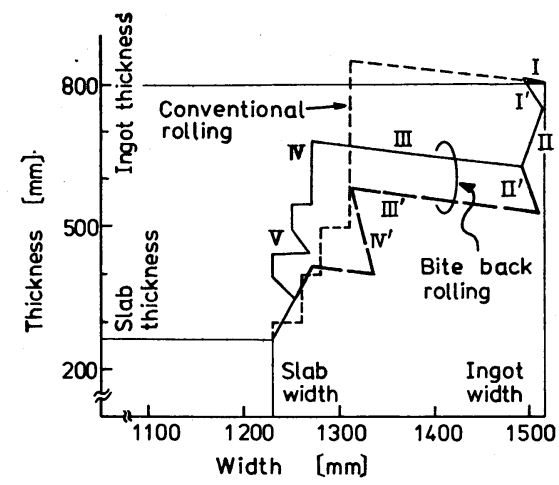

\begin{tabular}{c|l|l}
\hline Srage & \multicolumn{1}{|c|}{ Operation } & \multicolumn{1}{c}{ Description } \\
\hline I & Initial reduction & $\begin{array}{l}\text { Min. reduction for removal of primary scales } \\
\text { and elimination of ingot taper in directions } \\
\text { of width and thickness }\end{array}$ \\
\hline II & $\begin{array}{l}\text { Bite and back } \\
\text { rolling in di- } \\
\text { nection of thick- }\end{array}$ & $\begin{array}{l}\text { Formation of recesses at leading and tail } \\
\text { end of ingot, followed by effective flow of } \\
\text { metal to recesses }\end{array}$ \\
\hline III & $\begin{array}{l}\text { Bite and back } \\
\text { rolling in di- } \\
\text { rection of width }\end{array}$ & $\begin{array}{l}\text { Formation of recess at tail end of ingot, } \\
\text { followed by effective flow of metal to recess }\end{array}$ \\
\hline V & $\begin{array}{l}\text { Bite and back } \\
\text { rolling in di- } \\
\text { rection of thick- }\end{array}$ & $\begin{array}{l}\text { Formation of recesses at leading and tail end } \\
\text { absorption of dog bone formed at stage III }\end{array}$ \\
\hline V & $\begin{array}{l}\text { Correction of form } \\
\text { forsectinal light reduction while flowing metal } \\
\text { effectively to remaining recesses }\end{array}$ \\
\hline
\end{tabular}

Fig. 9. Example of comparison of pass schedule. (21 t capped steel ingots)

み拔け端に向かって, 被圧延材の厚み方向の形状を, $T$ 字状にして，ある時期にとのままパスを抜き去ることに より，啮み拔け端の鋼塊断面中央部が外に押し出され， メカニカルパイプを“0”に抑制できる．また，啮み込 み端に比べ，嚙み抜け端の方が，より大きい扇形の平面 形状を呈すので，後の幅圧下に扣けるメタルフローの調 整によりクロップレス形状を得ようとするるのである.

Fig. 7 は, 強圧下引き抜き圧延法の効果を明確にする ために，実鋼塊で実験した両端オーバラップ長さ比と圧 下率の関係を示す.

これがら，オーバラップは生成されず，スラブ断面が 突出することがわかる.

\section{3 字型圧延}

Fig. 8 に I 字型圧延の概略を示す.この圧延法は, 圧 延仕上がり前で，両端幅に中央幅を合わせるために中央 部分の幅圧延を行ら方法である.

この幅圧延に伴つて，ドックボーンが形成されるが，次 の厚み压下によつて全量幅に戻らず，長手方向の幅調整 が可能となる.

中央幅と両端幅の差 $\Delta W$ は, 鋼塊表面性状に応じて 調整することも可能である.

\section{5. 実機への適用と成果}

実機への各種分塊圧延法の適用に際しての検討から， キャップド鋼などの一般材については，嘴み戻し圧延法 とバーチカルフリー法を結合した，压延スケジュールと した. Fig. 9 K, $21 \mathrm{t}$ キャップド鋼塊で，幅圧下量 286 $\mathrm{mm}$ のパススケジュールの比較例を示す.

ここで，睖み戻し圧延による凹部先端の寸法変化は， 太い破線で示され $\mathrm{I}^{\prime} \sim \mathrm{IV}^{\prime}$ に推移する.幅圧下は, バー チカルフリー法の原則に従つている.

また，例えばステンレス鋼 JIS SUS 430 相当には，
Table 4. Reduction at tail end.

\begin{tabular}{|c|c|}
\hline $\begin{array}{c}\text { Soaking } \\
\text { temperature }\end{array}$ & $\begin{array}{l}\text { Reduction ratio of flattening } \\
\text { pass of the tail end }\end{array}$ \\
\hline $1200-1250^{\circ} \mathrm{C}$ & Min. $38.6-$ Max. $58.6^{\%}$ \\
\hline
\end{tabular}

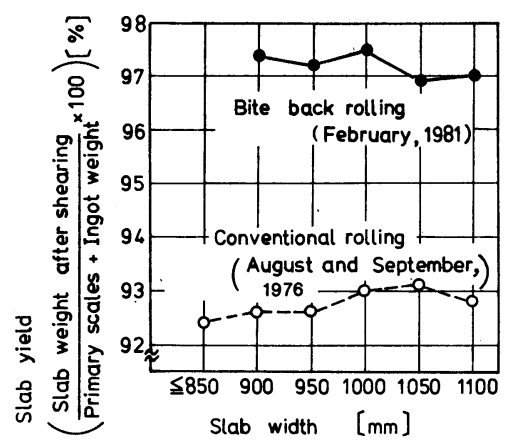

Fig. 10. Actual yield of $18 \mathrm{t}$ capped steel ingot. (Ingot size : Upper part $1222 \times 810 \mathrm{~mm}$ Lower part $1258 \times 910 \mathrm{~mm}$ )

強圧下引き抜き圧延法と I 字型圧延法を結合したものと した. 嘴み拔け端部の圧下率は, 幅圧下量に応じて変化 させる. 圧延負荷とオーバラップの減少程度, 及び最終 クロップ形状の綝り返しチェックにより得られた適正な 圧下率は, Table 4 に示される.

一例として, Fig. 10 K $18 \mathrm{t}$ キャップド鋼塊のスラ ブ幅別の実績歩留りを従来圧延法と比較して示した.

歩留りは, 従来圧延法に比して，4\%以上の向上とな り, その結果, 1980 年 12 月以降, 千葉・第 2 分塊工場 のキャップド鋼の良片歩留りは, $96 \%$ 以上を達成してい る.啮み戻し压延法により，スラブ幅精度も改善されて いる.

Fig. 11 Kステンレス鋼 JIS SUS 430 相当の圧延歩 留りの此較を示す. 強圧下引き抜き圧延法により，97.5 


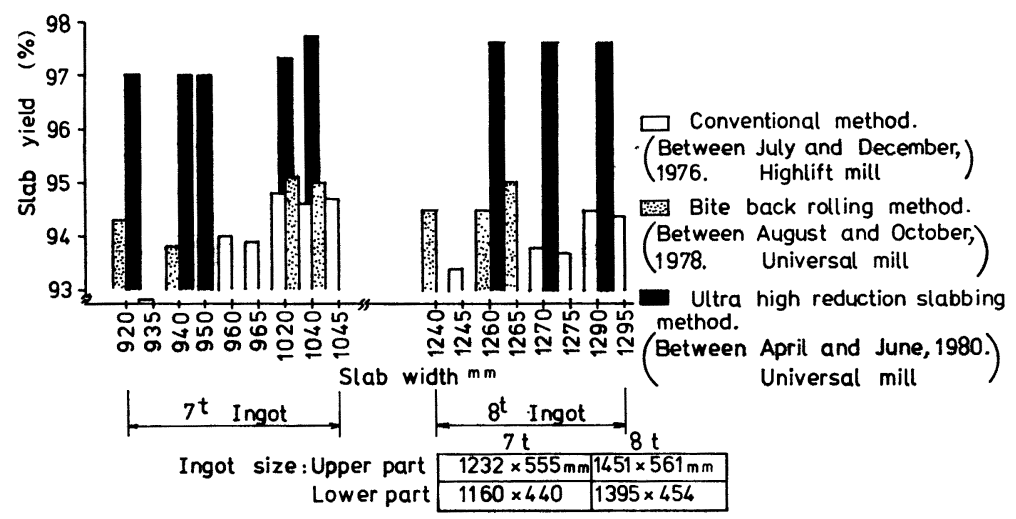

Fig. 11. Actual yield of 7 and $8 t$ stainless steel ingot.

\%の圧延歩留りを達成しており，I 字型圧延法により， コイルの幅精度も改善している.

な怙，強圧下引き抜き圧延法では，压延能率が向上し ているが，嘴み戻し圧延法では，鋼塊の一端に凹部を 1 回形成するのに $5 \sim 6 \mathrm{~s}$ の時間を要するものの, 然料 · 電力などの原単位アップを差し引いても，大きなコスト 低隇をみている。

\section{6. 結}

言

分塊压延に括いて生ずるクロップロスを減少させ，歩 留りの向上を計ることを目的とし，鋼を用いたモデル実 験などにより，クロップ部の基本的な变形挙動を検討し た. その結果に基づき，生産性をあまり下げずに，現状 設備のままで，大幅なクロップロスの低減が計られる， 新しい分塊圧延法を開発し, 平面形状の矩形化, および オーバラップの低隇に成功し, 歩留りの向上に大きく寄 与することができた.

本技術の 確立は, 分塊歩留りの 向上だけにとどまら ず，連続鋳造によつて製造されたスラブのサイジングミ ル，あるいは，ホットストリップミルやプレートミルな どの各種ミルへの幅広い適用が可能であろう．

\section{交献}

1）新日本製鉄：特公昭 42-25537

2 ）新日本製鉄：特開昭 49-15627
3 ) 片岡健二, 峰松隆嗣, 片山宏平, 柳沢高義, 温井 照男, 佐藤 孝：川崎製鉄技報, 10 (1970) 2, p. 200

4) I. M. MAckenziE: JISI, (1970) 4, p. 342

5 ）川崎製鉄：特開昭 53-93158

6 ) 金成昌平, 片岡健二, 中川吉左衛門, 松崎 実, 吉村英明，小川靖夫：鉄と鋼，65（1979）8, A 157

7 ) 松崎 実, 吉村英明, 小川靖夫, 金成昌平, 片岡 健二, 中川吉左衛門: Int. Conf. Manuf. Engng,

8 ）松崎 実, 吉村英明, 小川靖夫, 中里嘉夫, 金成 昌平：鉄と鋼，66 (1980), S 983

9 ) 金成昌平, 片岡健二, 中川吉左衛門, 松崎 実, 小川靖夫, 中里嘉夫, 吉村英明: 川崎製鉄技報, 12 (1980) 4, p. 571

10）松猗 実, 金成昌平, 小川靖夫, 中里嘉夫, 青山 勝：塑性と加工, 22 (1981) 240, p. 8

11）川崎製鉄：特開昭 54-97559

12）川崎製鉄：特願昭 54-163818

13）松崎 実, 吉村英明, 小川靖夫, 中里嘉夫：鉄と 鋼, 66 (1980), S 982

14）日本鉄銅協会共同研究会：第 51 回鋼板部会分塊 分科会 (1980) 川崎製鉄(株)（私信）

15）川村浩一，福田次男，馬田実，鉄と鋼，64 (1978), S 280

16）川村浩一, 福田次留, 佐藤 满：鉄と鋼，64 (1978), S 281

17) 生鴆栄次, 平沢猛志, 中内一郎, 摂待吉雄, 山岸 静直：日本鋼管技報，64 (1974)，p. 147 